\title{
Expression of FOXP3 mRNA is Decreased by Extract of
}

\section{Alkanna Frigida}

\author{
Mohammad Mehdi Ghorbani ${ }^{1}$, Reza Nekouian ${ }^{1}$ and Saeid Abediankenari ${ }^{2}$ \\ 1. Department of Biotechnology, University of Tehran, Tehran 15614, Iran \\ 2. Department of Immunology, University of Mazandaran, Babolsar 47416-95447, Mazandaran, Iran
}

Received: July 17, 2013 / Accepted: October 06, 2013 / Published: December 31, 2013.

\begin{abstract}
The immune system is a collection of cells and molecules; their task is identifying and destroying foreign cells and molecules. One of the most important cells of the immune system is $\mathrm{CD}^{4+} \mathrm{CD}^{25+}$ (Tregs) T-regulatory cells that regulates immune tolerance. FOXP3 is necessary for natural production and function of $\mathrm{CD}^{4+} \mathrm{CD}^{25+}$ regulatory $\mathrm{T}$ cells. Tregs are decreased in autoimmune diseases and are increased in tumors. In this study effect of Alkanna Frigida extract a medicinal plant was tested on FOXP3 expression. Given the importance of Tregs and FOXP3, nowadays, many studies about them are being conducted. The present study that was done for the first time showed that FOXP3 expression was decreased affected by Alkanna Frigida extract. Blood samples of intact volunteers were prepared. PBMCs of the samples were isolated on ficolls and different concentrations of Alkanna Frigida were added to PBMCs in RPMI 1,640 culture medium. After extracting total RNA, cDNA was synthesized using RT-PCR (reverse transcriptase-polymerase chain reaction). For assessment of gene expression real-time quantitative polymerase chain reaction was done. Effect of different concentrations of Alkanna Frigida on expression of FOXP3 mRNA showed that expression of FOXP3 mRNA was decreased. There was a statistically significant difference between control and test samples $(p<0.05)$. The study that expression of FOXP3 mRNA showed decreased affected by Alkanna Frigida. So its suggest that it is effective in preventing tumor cells by diminishing inhibitory effects of Tregs on NK, MAQ and other defensive cells, so a new horizon can be opened in complementary treatments of tumors.
\end{abstract}

Key words: Alkanna Frigida, tregs, FOXP3, tumor.

\section{Introduction}

The FOXP3 gene is expressed in $\mathrm{CD}^{4+} \mathrm{CD}^{25+}$ Tregs in natural conditions of body and determines number of these cells in peripheral blood. Expression of FOXP3 mRNA, differentiates Tregs $\mathrm{CD}^{4+} \mathrm{CD}^{25+}$ from other T-cells that lack regulatory function and also changes T-CD ${ }^{4+}$ to Tregs $\mathrm{CD}^{4+} \mathrm{CD}^{25+}$. FOXP3 (Fork head box protein 3), a member of the fork head or winged helix transcription factor family, is a nuclear protein expressed in Tregs (T-regulatory cells). This protein is encoded by FOXP3 gene and plays an important role in controlling the development and immunosuppressive function of Tregs [1-4]. Despite of an indispensable

Corresponding author: Reza Nekouian, Ph.D., research field: biotechnology. E-mail: reza_nik@unipune.ernet.in. role in preventing autoimmunity, prevalence of Tregs is augmented in the blood and the tumor microenvironment of patients with different kinds of tumors, such as breast and lung cancers, compared to healthy individuals, proposing a role of Tregs in repression anti-tumor immune responses [5-16]. Actually, since FOXP3 Tregs are immunosuppressive cells, a lot of studies have reported that their plentiful attendance in tumor infiltrates results in lowered survival in cancer patients. Also, clinical response of breast cancer to therapy is correlated with reductions in Tregs [14]. Despite a obvious role of FOXP3 in Tregs, FOXP3 protein expression is not only limited to the lymphocyte lineage but also exists in cancer cells of non-hematopoietic source [17-20]. Ladoire et al. [17] reported that a perfect histological respond to 
neoadjuvant breast cancer chemotherapy was correlated with lack of FOXP3 cells in tumor. Recently, observed that use of a FOXP3 aiming antisense morpholino oligomer to empty Tregs resulted in enhanced generation of antigen-specific $\mathrm{T}$ cells in response to peptide stimulation in peripheral blood mononuclear cells [21]. Normal expression of FOXP3 mRNA is pivotal for retaining Tregs action as well as self-equilibrium of the whole immune system. Mutations or lack of FOXP3 leads to lethal autoimmune diseases such as Graves, MS and Diabetes type I. On the other hand, massive expression of FOXP3 in different types of tumors, increases, boosts and activates tumor Tregs in different mechanisms and inhibits anti-tumor immune response, as well as high expression of FOXP3 elevates Tregs and this increase in Tregs, inhibits different immune cells as effector T cells, B-cells, NK-cells, NKT-cells, Dendritic cells and Macrophages [22-26], as a consequence, immune responses against tumor cells are reduced. Tregs are a member of the immune system that repress immune responses of other cells. This is a significant self-check made into the immune system to pull up extreme reactions. Treg cells have a significant role in autoimmune syndromes and cancers. They prevent emigration of effector immunocytes to purpose organs and inhibit their collaboration with APCs (antigen presenting cells). Studies in mice showed that diminition in Treg, results in the excitation of antitumor immune responses and tumor destruction.

Herbs are the basis of modern pharmacology and have been used to make numerous mainstream medicines. They are also used as a procedure to fight cancer. In this study we examined effect of Alkanna Frigida a herb that grows in the north part of Iran, on expression of FOXP3 mRNA. Alkanna Frigida belongs to the family of Boraginaceae and there are several genera in this family such as Alkanna, Anchusa, Nomosa and Borago (Papageorgiou el al., 1999; Hazra el al., 2004). Effective compounds of these plants are
Alkannin and Shikonin that are found in roots of these plants. These compounds have a wide spectrum of biological activities such as anti-inflammatory [27, 28], antibacterial [29] and anti-tumor effects [30]. They also inhibit Telomerase and Topoisomerase I enzymes [31, 32]. In this study we showed that Alkanna Frigida has an inhibitory effect on expression of FOXP3 in different concentrations.

\section{Materials and Methods}

\subsection{Cells and Reagents}

Ethanolic extract of Alkanna Frigida was prepared. Peripheral blood of healthy volunteers was obtained. Blood samples were collected in sterile falcons containing liquid EDTA. PBMCs (Peripheral blood mononuclear cells) of the samples were isolated on Ficoll (Sigma, USA) with use of density-gradient centrifugation. The PBMCs were washed with PBS (phosphate-buffered saline) for three times and then the cells were suspended in RPMI 1,640 medium with 10\% FCS (fetal calf serum). Number of PBMCs in each sample was counted $\left(6 \times 10^{7}\right)$. Each sample was divided equally into 12 parts and each part was plated in a 96-microwell cell culture plate. Different concentrations of Alkanna Frigida were prepared (1 $\mathrm{mg} / \mathrm{mL}, 5 \times 10^{-1} \mathrm{mg} / \mathrm{mL}, 2 \times 10^{-1} \mathrm{mg} / \mathrm{mL}, 1 \times 10^{-1}$ $\mathrm{mg} / \mathrm{mL}, 5 \times 10^{-2} \mathrm{mg} / \mathrm{mL}, 2 \times 10^{-2} \mathrm{mg} / \mathrm{mL}, 1 \times 10^{-2}$ $\mathrm{mg} / \mathrm{mL}, 5 \times 10^{-3} \mathrm{mg} / \mathrm{mL}, 2 \times 10^{-3} \mathrm{mg} / \mathrm{mL}, 1 \times 10^{-3}$ $\mathrm{mg} / \mathrm{mL}$ and $\left.5 \times 10^{-4} \mathrm{mg} / \mathrm{mL}\right)$.

\subsection{Cell Viability}

Freshly separated human PBMCs were plated in a 96-microwell cell culture plate at $5 \times 10^{6}$ cells per well with Alkanna Frigida at concentrations of $1,5 \times 10^{-1}, 2$ $\times 10^{-1}, 1 \times 10^{-1}, 5 \times 10^{-2}, 2 \times 10^{-2}, 1 \times 10^{-2}, 5 \times 10^{-3}, 2$ $\times 10^{-3}, 1 \times 10^{-3}$ and $5 \times 10^{-4} \mathrm{mg} / \mathrm{mL}$, so that for the first well as internal control, no Alkanna Frigida was added and respectively for wells from number 2 up to 12 , concentrations of $1,5 \times 10^{-1}, 2 \times 10^{-1}, 1 \times 10^{-1}, 5 \times 10^{-2}$, $2 \times 10^{-2}, 1 \times 10^{-2}, 5 \times 10^{-3}, 2 \times 10^{-3}, 1 \times 10^{-3}$ and $5 \times$ $10^{-4}$ per $\mathrm{mg} / \mathrm{mL}$ were added. The viable cells number 
were measured standard by the MTT (3-[4,5-dimethylthiazol-2-yl]-2,5-diphenyl-tetrazolium bromide) test and the trypan blue exclusion assay $12 \mathrm{~h}$, $24 \mathrm{~h}$ and $48 \mathrm{~h}$ after incubation at $37^{\circ} \mathrm{C}$ in humidified air with $5 \% \mathrm{CO}_{2}$.

\subsection{Real-Time PCR}

FOXP3 mRNA expressions were analyzed by real-time PCR. Total RNA of PBMCs was extracted by use of RNaxplus kit (Qiagen, Germany) and reverse transcribed to cDNA (RT-PCR) was performed on total RNA with primers in Table 1 and with the GeneAmp RNA PCR kit (Fermentase, Italy). Thermo cycling conditions included 40 cycles of denaturing at $94^{\circ} \mathrm{C}$ for $30 \mathrm{~s}$, annealing at $55^{\circ} \mathrm{C}$ for $15 \mathrm{~s}$, and extension at $72^{\circ} \mathrm{C}$ for $60 \mathrm{~s}$. The provided cDNAs were amplified using SYBR Green PCR Master Mix (Qiagen, Germany) according to the instructions of the producer in an iCycler IQ Sequence Detection System (Bio-Rad/MJ Research). Thermo cycling conditions consisted of 40 cycles of PCR initial activation step at $95^{\circ} \mathrm{C}$ for $5 \mathrm{~min}$, denaturation at $95^{\circ} \mathrm{C}$ for $10 \mathrm{~s}$ and combined annealing/extension at $60^{\circ} \mathrm{C}$ for $30 \mathrm{~s}$. Transcript levels of Foxp3 and $\beta$-actin were quantified by use of real-time quantitative PCR for the primers shown in Table 1.

\subsection{Statistical Analysis}

All experiments were done at least two times. The significance of the difference between the tests and controls were analyzed by a Student's $t$ test. All analysis was performed using SPSS 17 software. Significance was considered at $p<0.05$.

\section{Results}

\subsection{Effect of Alkanna Frigida on Human PBMCs Viability}

The MTT assay showed that no toxic and proliferation effects were observed after co-incubation of different concentrations of Alkanna Frigida with human PBMCs for up to $48 \mathrm{~h}$. This observation was corroborated by the trypan blue exclusion assay.

\subsection{Alkanna Frigida Decreases Expressions of FOXP3}

The study showed that $48 \mathrm{~h}$ after adding Alkanna Frigida to PBMCs in cell culture medium, level of FOXP3 mRNA expression was decreased. As showed in Diagram 1, expression of FOXP3 mRNA is decreased at concentrations of $1 \mathrm{mg} / \mathrm{mL}$ up to $5 \times 10^{-1}$, $2 \times 10^{-1}, 1 \times 10^{-1}, 5 \times 10^{-2}, 2 \times 10^{-2}, 1 \times 10^{-2}$ and $5 \times$ $10^{-3} \mathrm{mg} / \mathrm{mL}$ of Alkanna Frigida and expression of FOXP3 mRNA is increased at concentrations of $2 \times$ $10^{-3} \mathrm{mg} / \mathrm{mL}$ up to $1 \times 10^{-3} \mathrm{mg} / \mathrm{mL}$ and $5 \times 10^{-4} \mathrm{mg} / \mathrm{mL}$. The diagram is prepared base of real-time PCR results. It assessed FOXP3 mRNA expression in PBMCs by real-time PCR. It showed that expression of FOXP3 mRNA is decreased by Alkanna Frigida compared with control. In the Table 2, there are levels of FOXP3 mRNA expression on axis $\mathrm{Y}$ and concentrations of Alkanna Frigida on axis X. At concentration of Zero of Alkanna Frigida, It have maximum of expression and at concentration of $5 \times 10^{-3}$ of Alkanna Frigida, It have minimum of expression. In the gap between concentrations $1 \mathrm{mg} / \mathrm{mL}$ and $5 \times 10^{-3} \mathrm{mg} / \mathrm{mL}$ the diagram shows decline in expression and in the gap between concentrations $5 \times 10^{-3} \mathrm{mg} / \mathrm{mL}$ and $5 \times 10^{-4}$ $\mathrm{mg} / \mathrm{mL}$ the diagram shows rise in expression. The optimum concentration of Alkanna Frigida to decrease the expression of FOXP3 is $5 \times 10^{-3} \mathrm{mg} / \mathrm{mL}$.

\subsection{Statistical Analysis}

As shown in Table 2, acquired $p$-values between test samples and control samples by using SPSS 17 software and student's $t$-test show that there are significant differences between tests and controls. In comparison between controls in column 1 and tests in column 2 , the rate of $p$-value is 0.01 and there is no significant difference between them. In comparison between controls in column 1 and tests in column 3, the rate of $p$-value is 0.0001 and there is a significant difference between them. In comparison between controls in column 1 and tests in column 4 , the rate of $p$-value is 0.0004 and there is a significant difference between them. 
Table 1 Primers used in real-time PCR.

\begin{tabular}{|c|c|c|c|}
\hline Gene & Position & Method & Primer sequences \\
\hline & & & Forward-5'-CTGGCTCTCTCCCCAACTGA-3' \\
\hline & & & Reverse-5'-GCCCATCATCAGACTCTCTA-3' \\
\hline \multirow{2}{*}{$333 b p$} & $-3279 \mathrm{~A}>\mathrm{C}$ & & Forward-5'-TGGCTCTCTCCCCAACTGC-3' \\
\hline & Rs3761548 & & Reverse-5'-AGCCCATCATCAGACTCTCTA-3' \\
\hline FOXP3 & & $\begin{array}{l}\text { Real-time PCR } \\
\text { RT-PCR }\end{array}$ & \\
\hline & \multicolumn{2}{|c|}{ Forward-5 -CCCAGCTCAAGAGACCCCA-3 } & Forward-5'-CCCAGCTCAAGAGACCCCA-3' \\
\hline & & & Reverse-5'-GGGCTAGTCAGGAGGCTATTGTAAC-3' \\
\hline \multirow{2}{*}{$427 \mathrm{bp}$} & $-924 \mathrm{~A}>\mathrm{G}$ & & Forward-5'-CCAGCTCAAGAGACCCCG-3' \\
\hline & Rs2232365 & & Reverse- 5'-GCTATTGTAACAGTCCTGGCAAGTG-3' \\
\hline$\beta$-Actin: & & & $\begin{array}{l}\text { Forward-5'-TGGCCACGGCTGCTTCCAGC-3' } \\
\text { Reverse-5'-AGGAGGAGCAATGATCTTGAT-3' }\end{array}$ \\
\hline
\end{tabular}

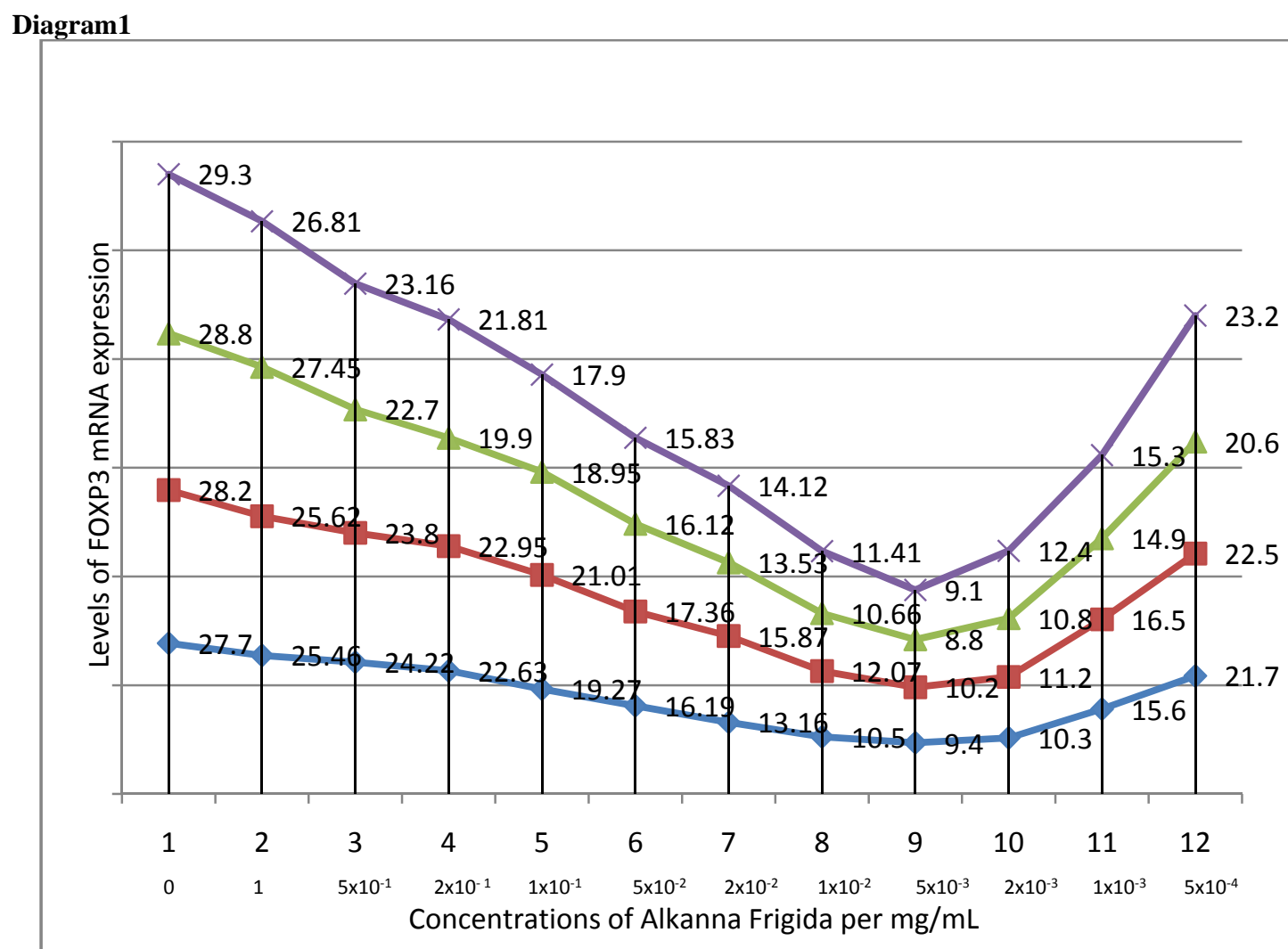

Table 2 Comparison of means of tests and controls.

\begin{tabular}{|c|c|c|c|c|c|c|c|c|c|c|c|c|}
\hline Alkanna Frioida & 1 & 2 & 3 & 4 & 5 & 6 & 7 & 8 & 9 & 10 & 11 & 12 \\
\hline concentrations & Zero & $\begin{array}{l}1 \\
\mathrm{mg} / \mathrm{mL}\end{array}$ & $\begin{array}{l}5 \times 10^{-1} \\
\mathrm{mg} / \mathrm{mL}\end{array}$ & $\begin{array}{l}2 \times 10^{-1} \\
\mathrm{mg} / \mathrm{mL}\end{array}$ & $\begin{array}{l}1 \times 10^{-1} \\
\mathrm{mg} / \mathrm{mL}\end{array}$ & $\begin{array}{l}5 \times 10^{-2} \\
\mathrm{mg} / \mathrm{mL}\end{array}$ & $\begin{array}{l}2 \times 10^{-2} \\
\mathrm{mg} / \mathrm{mL}\end{array}$ & $\begin{array}{l}1 \times 10^{-2} \\
\mathrm{mg} / \mathrm{mL}\end{array}$ & $\begin{array}{l}5 \times 10^{-3} \\
\mathrm{mg} / \mathrm{mL}\end{array}$ & $\begin{array}{l}2 \times 10^{-3} \\
\mathrm{mg} / \mathrm{mL}\end{array}$ & $\begin{array}{l}1 \times 10^{-3} \\
\mathrm{mg} / \mathrm{mL}\end{array}$ & $\begin{array}{l}5 \times 10^{-4} \\
\mathrm{mg} / \mathrm{mL}\end{array}$ \\
\hline \multirow{4}{*}{ Mean } & 27.7 & 25.46 & 24.22 & 22.63 & 19.27 & 16.19 & 13.16 & 10.5 & 9.4 & 10.3 & 15.6 & 21.7 \\
\hline & 28.2 & 25.62 & 23.80 & 22.95 & 21.02 & 17.36 & 15.87 & 12.07 & 10.2 & 11.2 & 16.5 & 22.5 \\
\hline & 28.8 & 27.45 & 22.70 & 19.90 & 18.95 & 16.12 & 13.53 & 10.66 & 8.8 & 10.8 & 14.9 & 20.6 \\
\hline & 29.3 & 26.81 & 23.16 & 21.81 & 17.90 & 15.83 & 14.12 & 11.41 & 9.1 & 12.4 & 15.3 & 23.2 \\
\hline$p$ & & 0.01 & 0.0001 & 0.0004 & $<0.0001$ & $<0.0001$ & $<0.0003$ & $<0.0003$ & $<0.0004$ & $<0.0001$ & $<0.0001$ & $<0.0001$ \\
\hline
\end{tabular}


In comparison between controls in column 1 and tests in column 5 , the rate of $p$-value is $<0.0001$ and there is a significant difference between them. In comparison between controls in column 1 and tests in column 6 , the rate of $p$-value is $<0.0001$ and there is a significant difference between them. In comparison between controls in column 1 and tests in column 7, the rate of $p$-value is 0.0003 and there is a significant difference between them. In comparison between controls in column 1 and tests in column 8 , the rate of $p$-value is 0.0001 and there is a significant difference between them. In comparison between controls in column 1 and tests in column 9 , the rate of $p$-value is $<$ 0.0004 and there is a significant difference between them. In comparison between controls in column 1 and tests in column 10, the rate of $p$-value is $<0.0001$ and there is a significant difference between them. In comparison between controls in column 1 and tests in column 11 , the rate of $p$-value is $<0.0001$ and there is a significant difference between them. In comparison between controls in column 1 and tests in column 12, the rate of $p$-value is $<0.0001$ and there is a significant difference between them.

\section{Discussion}

FOXP3 gene is an intracellular marker that its expression indicates activity of T-regulatory cells. The gene expresses in $\mathrm{CD}^{4+} \mathrm{CD}^{25+}$ Treg cells in physiologic conditions, it encodes a protein of Fork head/winged-helix transcription factors family and this protein plays a pivotal role in regulating of activity and number of Treg cells. Treg cells expressing the FOXP3 transcription factor play a pivotal role in the protection against unwanted $\mathrm{T}$ cell activation and autoimmune diseases, while still allowing a fast and effective immunological response to pathogens. Tregs and FOXP3 have become important therapeutic aims both in autoimmunity and cancer [33]. However, inhibiting Treg function to augment tumor refusal carries perils associated with developing autoimmunity. On the other hand, augmenting Treg function to control autoimmunity may predispose to the improvement of cancer. There has been an explosion of literature focusing on the role of Tregs in several setting including cancer immunity, autoimmunity, transplantation, tolerance allergic responses and microbial immunity [34-38]. Tregs can be described as a T-cell population that functionally suppresses an immune response by influencing the activity of another cell type [34-39]. More studies are therefore needed to better determine the different signaling pathways of FOXP3, thereby helping in the design of target-specific therapies. It is now obvious that FOXP3 is expressed by plenty of tumor cells such as breast cancer cells, however its role is controversial and not clearly perceived with its capability to act as a tumor suppressor in some cancer cells and a prognostic marker in others $[40,41]$. The role of FOXP3 in tumor cells is still unknown as it appears that expression of FOXP3 in tumor cells may be a mechanism of tumor-mediated immune suppression, similar to its function in Tregs but on the other hand, FOXP3 expression itself may repress tumor growth, by suppressing the expression of tumor oncogenes [42, 43]. Recent studies have manifested that $\mathrm{CD}^{4+} \mathrm{CD}^{25+}$ FOXP3 naturally occurring regulatory $\mathrm{T}$ cells cumulate in environment of tumor and repress responds of tumor specific $\mathrm{T}$ cell, thereby, hampering tumor rejection [44] as well as many studies about several types of cancer have demonstrated increased levels of Tregs in peripheral blood $[45,46]$.

In this study we tested the effect of different concentrations of Alkanna Frigida on FOXP3 gene expression in cell culture medium containing PBMCs. As the results in diagram 1 show, at concentrations of $1,5 \times 10^{-1}, 2 \times 10^{-1}, 1 \times 10^{-1}, 5 \times 10^{-2}, 2 \times 10^{-2}, 1 \times$ $10^{-2}$ and $5 \times 10^{-3}$ per $\mathrm{mg} / \mathrm{mL}$ of Alkanna Frigida, expression of FOXP3 mRNA is decreased and at concentrations of $2 \times 10^{-3}, 1 \times 10^{-3}$ and $5 \times 10^{-4}$ $\mathrm{mg} / \mathrm{mL}$, expression of FOXP3 mRNA is increased. The best concentration (the optimum concentration) 
of Alkanna Frigida for decreasing of FOXP3 mRNA expression is $5 \times 10^{-3} \mathrm{mg} / \mathrm{mL}$ of Alkanna Frigida and at this concentration, FOXP3 mRNA expression is the lowest so Alkanna Frigida acts as a reducing agent of FOXP3 gene expression. Considering that the FOXP3 gene activity is determinant of the number of Treg cells, so in this study, we indirectly conclude Alkanna Frigida reduces the number of Treg cells in the peripheral blood by reducing FOXP3 gene expression. There are two types of Treg cells in human, thymic and acquired type. There are FOXP3 proteins mainly in the thymus, where the majority of Tregs entitled normal Treg cells are formed. A subset of $\mathrm{TCD}^{4+} \mathrm{CD}^{25+}$ cells in the thymus affected by FOXP3 protein are converted into $\mathrm{TCD}^{4+} \mathrm{CD}^{25+}$ FOXP3 cells that are named natural Treg cells. Considering that the FOXP3 expression is reduced by Alkanna Frigida and subsequently FOXP3 protein is decreased, so we can conclude that the Treg cells in the thymus decrease. The Treg cells are the main source of producing IL-10 and TGF- $\beta$. Note that Alkanna Frigida reduces Treg cells so we can say that Alkanna Frigida can reduce the synthesis of IL-10 (data not shown) and TGF- $\beta$ by Treg cells and according to the reduction of IL-10 and TGF- $\beta$, we will have reduction of all the works related to IL-10 and TGF- $\beta$. In peripheral blood, $\mathrm{TCD}^{4+} \mathrm{CD}^{25-}$ cells affected by TGF- $\beta$ are converted to Treg cells and are called, Peripheral Treg cells. Now according to the inhibitory effect of Alkanna Frigida on expression of FOXP3 gene and Treg cells production, we can conclude that Alkanna Frigida reduces Peripheral Treg cells by reducing the production of TGF- $\beta$ from Treg cells. Treg cells have an important role in preventing immune responses against tumor. The more number of these cells in peripheral blood is, the worse prognosis is. It has showed that in patients with Lung or Ovarian cancers, Treg cells have increased. The increase in breast cancer and other tumors also have been reported $[45,46]$. Considering that high increase of FOXP3 expression has been found in all types of tumor cells this would cause, increase in Treg cells and as a consequence, inhibition of immune cells and also reduce in immune response to tumor cells, so we can use Alkanna Frigida to decrease FOXP3 expression and Treg numbers in different concentrations specially concentration of $5 \times 10^{-3} \mathrm{mg} / \mathrm{mL}$, hereby inhibitory effect of Tregs on immune cells such as NK, NKT, $\mathrm{B}$-cell, Macrophage and effector $\mathrm{T}$ cell will be very low and as a consequence these cells can fight against tumor cells. Recently a research showed that the number of Tregs and mRNA expression of functional molecules of Tregs are correlated to airway allergy and disease intensity [47]. It was also demonstrated that patients with asthma have reduced FOXP3 protein expression within their Tregs [48]. In addition, diminished expression of FOXP3 gene was recently reported in nasal secretions of patients with AR (Allergic rhinitis) [49]. Considering that there are decreased expression of FOXP3 gene and reduced number of Tregs in allergic and autoimmune diseases so we can not use Alkanna Frigida in patients with these diseases. Accumulation of Tregs in a tumor is caused by multiple factors, including increased proliferation, decreased apoptosis, altered expression of chemokine receptor and cell-surface markers. In order for the immune system to be able to respond to the tumor cells, FOXP3 gene expression and consequently Treg cells should be reduced until inhibitory action of Treg cells on immune cells such as NK, NKT, B-cell, Macrophage and dendritic cells should be reduced and these cells can react against tumor cells. Due to the decreased expression of FOXP3 by Alkanna Frigida and subsequently reduce in number of Treg cells we can make use of Alkanna Frigida to enhance the effectiveness of tumor and cancer treatment methods. In the study, it was shown that FOXP3 expression has been reduced by Alkanna Frigida and this reduction can decrease Treg cells number and also IL-10 and TGF- $\beta$ which ultimately can help reduce of tumor cells number. 


\section{References}

[1] J.D. Fontenot, M.A. Gavin, A.Y. Rudensky, FOXP3 programs the development and function of $\mathrm{CD}^{4+} \mathrm{CD}^{25+}$ regulatory T cells, Nat. Immunol 4 (2003) 330-336.

[2] S. Sakaguchi, M. Ono, R. Setoguchi, H. Yagi, S. Hori, Z. Fehervari, et al., FOXP3 $+\mathrm{CD}^{25+} \mathrm{CD}^{4+}$ natural regulatory $\mathrm{T}$ cells in dominant self-tolerance and autoimmune disease, Immunol. Rev. 212 (2006) 8-27.

[3] H. Yagi, T. Nomura, K. Nakamura, S. Yamazaki, T. Kitawaki, S. Hori, et al., Crucial role of FOXP3 in the development and function of human $\mathrm{CD}^{25+} \mathrm{CD}^{4+}$ regulatory $\mathrm{T}$ cells, Int. Immunol. 16 (11) (2004) 1643-1656.

[4] S. Hori, S. Sakaguchi, FOXP3: A critical regulator of the development and function of regulatory $\mathrm{T}$ cells, Microbes Infect. 6 (2004) 745-751.

[5] E.Y. Woo, H. Yeh, C.S. Chu, K. Schlienger, R.G. Carroll, J.L. Riley, et al., Cutting edge: Regulatory $\mathrm{T}$ cells from lung cancer patients directly inhibit autologous $\mathrm{T}$ cell proliferation, J. Immunol. 168 (9) (2002) 4272-4276.

[6] A.M. Wolf, D. Wolf, M. Steurer, G. Gastl, E. Gunsilius, et al., Increase of regulatory $\mathrm{T}$ cells in the peripheral blood of cancer patients, Clin. Cancer Res. 9 (2003) 606-612.

[7] M. Viguier, F. Lemaitre, O. Verola, M.S. Cho, G. Gorochov, L. Dubertret, et al., FOXP3 expressing $\mathrm{CD}^{4+} \mathrm{CD}^{25}$ (high) regulatory $\mathrm{T}$ cells are overrepresented in human metastatic melanoma lymph nodes and inhibit the function of infiltrating T cells, J. Immunol. 173 (2004) 1444-1453.

[8] S.A. Perez, M.V. Karamouzis, D.V. Skarlos, A. Ardavanis, N.N. Sotiriadou, E.G. Iliopoulou, et al., $\mathrm{CD}^{4+} \mathrm{CD}^{25+}$ regulatory T-cell frequency in HER-2/neu (HER)-positive and HER-negative advanced-stage breast cancer patients, Clin. Cancer Res. 13 (2007) 2714-2721.

[9] L.A. Ormandy, T. Hillemann, H. Wedemeyer, M.P. Manns, T.F. Greten, F. Korangy, Increased populations of regulatory $\mathrm{T}$ cells in peripheral blood of patients with hepatocellular carcinoma, Cancer Res. 65 (2005) 2457-2464.

[10] T.J. Curiel, G. Coukos, L. Zou, X. Alvarez, P. Cheng, P. Mottram, et al., Specific recruitment of regulatory T cells in ovarian carcinoma fosters immune privilege and predicts reduced survival, Nat. Med. 10 (2004) 942-949.

[11] P.E. Fecci, D.A. Mitchell, J.F. Whitesides, W. Xie, A.H. Friedman, G.E. Archer, et al., Increased regulatory T-cell fraction amidst a diminished $\mathrm{CD}^{4}$ compartment explains cellular immune defects in patients with malignant glioma, Cancer Res. 66 (2006) 3294-3302.

[12] E.Y. Woo, C.S. Chu, T.J. Goletz, K. Schlienger, H. Yeh, G. Coukos, et al., Regulatory $\mathrm{CD}^{4(+)} \mathrm{CD}^{25(+)} \mathrm{T}$ cells in tumors from patients with early-stage non-small cell lung cancer and late-stage ovarian cancer, Cancer Res. 61 (2001) 4766-4772.

[13] U.K. Liyanage, T.T. Moore, H.G. Joo, Y. Tanaka, V. Herrmann, G. Doherty, et al., Prevalence of regulatory T cells is increased in peripheral blood and tumor microenvironment of patients with pancreas or breast adenocarcinoma, J. Immunol. 169 (2002) 2756-2761.

[14] F. Martin, S. Ladoire, G. Mignot, L. Apetoh, F. Ghiringhelli, Human FOXP3 and cancer, Oncogene 29 (2010) 4121-4129.

[15] S. Hinz, L. Pagerols-Raluy, H.H. Oberg, O. Ammerpohl, S. Grussel, B. Sipos, et al., FOXP3 expression in pancreatic carcinoma cells as a novel mechanism of immune evasion in cancer, Cancer Res. 67 (2007) 8344-8350.

[16] M.A. Morse, A.A. Secord, K. Blackwell, A.C. Hobeika, G. Sinnathamby, T. Osada, et al., MHC class I-presented tumor antigens identified in ovarian cancer by immunoproteomic analysis are targets for T-cell responses against breast and ovarian cancer, Clin. Cancer Res. 17 (2011) 3408-3419.

[17] S. Ladoire, L. Arnould, L. Apetoh, B. Coudert, F. Martin, B. Chauffert, et al., Pathologic complete response to neoadjuvant chemotherapy of breast carcinoma is associated with the disappearance of tumor-infiltrating FOXP3+ regulatory T cells, Clin. Cancer Res. 14 (2008) 2413-2420.

[18] L.M. Ebert, B.S. Tan, J. Browning, S. Svobodova, S.E. Russell, N. Kirkpatrick, et al., The regulatory $\mathrm{T}$ cell-associated transcription factor FOXP3 is expressed by tumor cells, Cancer Res. 68 (2008) 3001-3009.

[19] T. Zuo, L. Wang, C. Morrison, X. Chang, H. Zhang, W. $\mathrm{Li}$, et al., FOXP3 is an X-linked breast cancer suppressor gene and an important repressor of the HER-2/ErbB2 oncogene, Cell 129 (7) (2007) 1275-1286.

[20] R. Wang, L. Kozhaya, F. Mercer, A. Khaitan, H. Fujii, D. Unutmaz, Expression of GARP selectively identifies activated human FOXP3+ regulatory T cells, Proc. Natl. Acad. Sci. USA 106 (32) (2009) 13439-13444.

[21] M.A. Morse, A. Hobeika, D. Serra, K. Aird, M. McKinney, A. Aldrich, et al., Depleting regulatory T cells with arginine-rich, cell-penetrating, peptide-conjugated morpholino oligomer targeting FOXP3 inhibits regulatory T-cell function, Cancer Gene Ther. 19 (2012) 30-37.

[22] E.M. Shevach, $\mathrm{CD}^{4+} \mathrm{CD}^{25+}$ suppressor $\mathrm{T}$ cells: More questions than answers, Nat. Rev. Immunol. 2 (6) (2002) 389-400.

[23] S. Sakaguchi, Naturally arising FOXP3-expressing $\mathrm{CD}^{25+} \mathrm{CD}^{4+}$ regulatory $\mathrm{T}$ cells in immunological tolerance to self and non-self, Nat. Immunol. 6 (4) (2005) 345-352.

[24] H. Von Boehmer, Mechanisms of suppression by suppressor T cells, Nat. Immunol. 6 (4) (2005) 338-344. 
[25] Q. Tang, J.A. Bluestone, The FOXP3+ regulatory T cell: A jack of all trades, master of regulation, Nat. Immunol. 9 (3) (2008) 239-244.

[26] D.A.A. Vignali, L.W. Collison, C.J. Workman, How regulatory T cell works, Nat. Rev. Immunol. 8 (7) (2008) 523-532.

[27] D. Gao, M. Kakuma, Reaction of beta-alkannin (shikonin) with reactive oxygen species: Detection of beta-alkannin free radicals, Bioorg. Med. Chem. 8 (11) (2000) 2561-2569.

[28] A.P. Kourounakis, A.N. Assimopoulou, V.P. Papageorgiou, Alkannin and shikonin: Effect on free radical processes and on inflamayion - a preliminary pharmacochemical investigation, Arch. Pharm. (Weinheim) 335 (6) (2002) 262-266.

[29] C.C. Shen, W.J. Syu, C.H. Lin, G.H. Lee, C.M. Sun, Antimicrobial activities of naphthazarines from Arnebia euchroma, J. Nat. Prod. 65 (12) (2002) 1857-1862.

[30] Z. Wu, L.J. Wu, L.H. Li, S. Tashimo, S. Onodera, T. Ikejima, Shikonin ragulates Hela cell death ria caspase-3 activation and blockage of DNA synthesis, J. Asian. Nat. Prod. Res. 6 (3) (2004) 155-166.

[31] Z.F. Plyta, T. Li, V.P. Papageorgiu, A.S. Mellidis, A.N. Assimopoulou, E.N. Pitsinos, et al., Inhibition of topoisomerase I by naphtoquinone derivatives, Bioorg. Med. Chem. Lett. 8 (23) (1998) 3385-3390.

[32] Q. Lu, W. Liu, J. Ding, J. Cai, W. Duan, Shilonin derivatives: Synthesis and inhibition of human telomerase, Bioorg. Med. Chem. Lett. 12 (10) (2002) 1375-1378.

[33] H. Katoh, P. Zheng, Y. Liu, Signalling through FOXP3 as an X-Linked tumor suppressor, Int. J. Biochem. Cell Biol. 42 (11) (2010) 1784-1787.

[34] B.H. Waksman, Tolerance, the thymus, and suppressor $\mathrm{T}$ cells, Clin. Exp. Immunol. 28 (3) (1977) 363-374.

[35] W. Zou, Regulatory $\mathrm{T}$ cells, tumour immunity and immunotherapy, Nat. Rev. Immunol. 6 (2006) 295-307.

[36] T.J. Curiel, Tregs and rethinking cancer immunotherapy, J Clin Invest. 117 (2007) 1167-1174.

[37] T.Y. Ha, The role of suppressor T cells in mycobacterial infection, Korean Lepr Bull. 41 (2008) 3-25.

[38] T.Y. Ha, The role of suppressor $\mathrm{T}$ cells in bacterial infections, KAST Rev. Modern Sci. \& Technol. 4 (2008) 105-120.

[39] P.A. Mudd, B.N. Teague, A.D. Farris, Regulatory T cells and systemic lupus erythematosus, Scand J. Immunol. 64 (2006) 211-218.

[40] S. Douglass, S. Ali, A.P. Meeson, D. Browell, J.A. Kirby, The role of FOXP3 in the development and metastatic spread of breast cancer, Cancer Metastasis Rev. 31 (2012) 843-854.

[41] R.J. de Leeuw, S.E. Kost, J.A. Kakal, B.H. Nelson, The prognostic value of FOXP3+ tumor-infiltrating lymphocytes in cancer: A critical review of the literature, Clin. Cancer Res. 18 (2012) 3022-3029.

[42] T. Zuo, L. Wang, C. Morrison, X. Chang, H. Zhang, W. $\mathrm{Li}$, et al., FOXP3 is an X-linked breast cancer suppressor gene and an important repressor of the HER-2/ErbB2 oncogene, Cell 129 (7) (2007) 1275-1286.

[43] T. Zuo, R. Liu, H. Zhang, X. Chang, Y. Liu, L. Wang, et al., FOXP3 is a novel transcriptional repressor for the breast cancer oncogene SKP2, J. Clin. Invest. 117 (12) (2007) 3765-3773.

[44] N. Kobayashi, N. Hiraoka, W. Yamagami, H. Ojima, Y. Kanai, T. Kosuge, et al., FOXP3+ regulatory $\mathrm{T}$ cells affected the development and progression of hepatocarcinogenesis, Clin. Cancer Res. 13 (2007) 902-911.

[45] L.A. Ormandy, T. Hillemann, H. Wedemeyer, M.P. Manns, T.F. Greten, F. Korangy, Increased populations of regulatotr $\mathrm{T}$ cells in peripheral blood of patients with hepatocellular carcinoma, Cancer Res. 65 (2005) 2457-2464.

[46] G.C. Cesana, G. DeRaffele, S. Cohen, D. Moroziewicz, J. Mitcham, J. Stoutenburg, et al., Characterization of $\mathrm{CD} 25+\mathrm{CD} 4+$ regulatory $\mathrm{T}$ cells in patients treated with high-dose interleukin-2 for metastatic melanoma or renal cell carcinoma, J. Clin. Oncol. 24 (2006) 1169-1177.

[47] J.H. Lee, H.H. Yu, L.C. Wang, Y.H. Yang, Y.T. Lin, B.L. Chiang, The levels of $\mathrm{CD}^{25+} \mathrm{CD}^{4+}$ regulatory $\mathrm{T}$ cells inpediateric patients with allergic rhinitis and bronchial asthma, Clin. Exp. Immunol. 148 (2007) 53-63.

[48] S. Provoost, T. Maes, Y.M. van Durme, P. Gevaret, C. Bachert, C.B. Schmidt-Weber, et al., Decreased FOXP3 protein expression in patients with asthma, Allergy 64 (10) (2009) 1539-1546.

[49] S.M. Lee, B. Gao, M. Dahl, K. Calhoun, D. Fang, Decreased FOXP3 gene expression in the nasal secretions from patients with allergic rhinitis, Otolaryngol Head Neck Surg. 140 (2009) 197-201. 